IZA DP No. 9743

Business in Genocide:

Understanding and Avoiding Complicity

Nora Stel

Wim Naudé

February 2016 


\title{
Business in Genocide: Understanding and Avoiding Complicity
}

\author{
Nora Stel \\ MSM and Utrecht University \\ Wim Naudé \\ MSM, Maastricht University \\ and IZA
}
Discussion Paper No. 9743
February 2016

\author{
IZA \\ P.O. Box 7240 \\ 53072 Bonn \\ Germany \\ Phone: +49-228-3894-0 \\ Fax: +49-228-3894-180 \\ E-mail: iza@iza.org
}

\begin{abstract}
Any opinions expressed here are those of the author(s) and not those of IZA. Research published in this series may include views on policy, but the institute itself takes no institutional policy positions. The IZA research network is committed to the IZA Guiding Principles of Research Integrity.

The Institute for the Study of Labor (IZA) in Bonn is a local and virtual international research center and a place of communication between science, politics and business. IZA is an independent nonprofit organization supported by Deutsche Post Foundation. The center is associated with the University of Bonn and offers a stimulating research environment through its international network, workshops and conferences, data service, project support, research visits and doctoral program. IZA engages in (i) original and internationally competitive research in all fields of labor economics, (ii) development of policy concepts, and (iii) dissemination of research results and concepts to the interested public.
\end{abstract}

IZA Discussion Papers often represent preliminary work and are circulated to encourage discussion. Citation of such a paper should account for its provisional character. A revised version may be available directly from the author. 
IZA Discussion Paper No. 9743

February 2016

\section{ABSTRACT \\ Business in Genocide: Understanding and Avoiding Complicity*}

Genocides and mass atrocities do not arise spontaneously, but tend to be meticulously sourced and managed. As such the concern in this paper is with the role of businesses in these processes, with a particular focus on the agency and decision making of entrepreneurs and managers. We critically explore the specific role entrepreneurs and businesses played in three of the most uncontested genocides of recent history: the Jewish, Kurdish, and Darfurian genocides. From this literature we seek to distill key insights into what entrepreneurs and socially responsible businesses can do to lessen the tensions, misunderstandings, exclusions, and marginalization that are among the complex causes of genocides and other mass atrocities. In order to better understand the complicity of business there is a need for a shift from diagnostic attention on how businesses are engaged in genocide to a more analytical exploration of why businesses have made the choices they did in the process of their engagement with genocide. This is also necessary to advance the debate on how to hold businesses accountable for gross human rights violations and moreover to provide incentives for businesses not only to avoid doing harm but also to proactively, preventively strive to protect and extend human rights.

JEL Classification: D74, O19, L26, N40, M14

Keywords: business, entrepreneurship, genocide, mass killings, conflict, development

Corresponding author:

Wim Naudé

Maastricht School of Management (MSM)

PO Box 1203

6201 BE Maastricht

The Netherlands

E-mail:w.naude@maastrichtuniversity.nl

\footnotetext{
* This is a draft of a chapter that has been accepted for publication by Oxford University Press in the forthcoming book Anderton, C.H. and Brauer, J. eds. Economic Aspects of Genocides, Mass Atrocities, and their Prevention, due for publication in 2016.
} 


\section{Introduction}

Along with the United Nations (UN) Genocide Convention, we define genocide as mass atrocity committed with the intent to destroy, in whole or in part, a national, ethical, racial or religious group (Kelly, 2012) [p.357]. Entrepreneurs and their businesses are not often associated with genocides and other mass atrocities (GMAs). This is no doubt due to the fact that, by and large, business, enterprise, and commercial interactions between people are not zero-sum games, but are based on mutual benefits. Violent conflict, especially to the extreme embodied in genocides, destroys markets, infrastructure, assets, and resources; undermines trust; and, as such, undermines trade and investment (Brueck et al., 2013). Indeed, where human rights are respected and defended, businesses flourish (Mallinson as quoted in Chella (2012) p.295). Nevertheless, genocides take place too often to maintain that there may never be vested interests for businesses to be complicit in such gross human rights violations (Stokes and Gabriel, 2010).

Describing and understanding business complicity in GMAs is the main purpose of this paper. As the substantial literature on the topic has convincingly illustrated, GMAs do not arise spontaneously, but tend to be meticulously sourced and managed. Entrepreneurs and businesses (firms, companies) may be particularly effective vehicles through which such planning, management, and execution, not to mention financing, of GMAs are facilitated. As such, our interest is not the business of genocide but rather business in genocide (i.e., the role of businesses in these processes), with a particular focus on the agency and decision making of entrepreneurs and managers.

In the literature, the role of business in genocides is hardly ever discussed separately from other mass atrocities. But while all genocides are mass atrocities, not all mass atrocities are genocides. Mass atrocities refer to scale and quantity, whereas genocide refers to intentionality and quality (Kelly, 2012) [p.357]. Indeed, the wealth of studies on corporate complicity in GMA as a broader category obscures how little we know about the role of businesses in genocides specifically. Businesses general complicity in military regimes and dictatorships, or deployment in war zones and conflict areas, is crucially different from their specific complicity in particular mass atrocities (Kaleck and Saage-Maass, 2010) [p.702-3]. This is so, first, because of the intent clause in the genocide definition. While mass atrocities can be a means toward another end or a byproduct of a specific development or policy, genocide is per definition an end in its own right. This distinction particularly matters, second, in light of the companies valuable reputation. While it could be argued that being associated with any mass atrocity is bad for business, it is safe to say that the publicwhich consists of customers, clients, voters, and policymakersis putatively more concerned about genocide, the crime of crimes (Kelly, 2012) [p.339]. Unlike the more generic container concept of mass atrocities, which might easier be sold as unavoidable in certain regions, sectors, or situations, the label of genocide has a sociopolitical explosiveness, and generates a degree of media attention, that brings with it an exceptional vulnerability to reputational damage through naming and shaming campaigns (Jacobs, 2008) $[\text { p.49 }]^{1}$. For this reason, as well as for the sake of conceptual

${ }^{1}$ Several examples serve to illustrate the apparent stakes involved for businesses in avoiding the label of genocide. Oil companies such as Shell and Chevron in Nigeria do not deny mass atrocities take place, 
and empirical demarcation, this paper focuses on corporate complicity in genocide specificallyeven if many of our observations might apply to other mass atrocities as well.

There are too many examples in history of business in genocide. One can think of the role of the Dutch and British East India Companies, the worlds first multinationals, in Asia or in the slave trade (Stephens, 2002; Chella, 2012; Slim, 2012); IBMs complicity in the Holocaust (Black, 2001; Stephens, 2002); the collaboration between Hollywood film studios and the Nazis (Urwand, 2013); and the controversies surrounding multinational corporations in resource-rich developing countries (Clapham and Jerbi, 2001; Cooper, 2002; Rieth and Zimmer, 2004; Kaeb, 2008; Chella, 2012). On the other hand, there are also instances of business playing peace-promoting and peace-supporting roles (Naudé, 2009). Sweetman (2009) for instance mentions that businesses acted as early warning systems in Burundi during the Rwandan genocide and in Macedonia during the Yugoslavian conflict and that this reduced violence. However, a holistic analysis of the involvement of commercial organizations in genocide is so far unavailable. This paper aims to start to fill this gap by critically exploring the status quo of the academic literature on corporate complicity in genocide in light of case-based evidence in order to contribute to advancing conceptualization of the phenomenon. Ultimately, we seek to generate more insights into what productive entrepreneurship and socially responsible businesses can do to lessen the tensions, misunderstandings, exclusions, and marginalization that are among the complex causes of genocides and other mass atrocities.

We commence in section 2 by mapping the scholarly debates about what manifests, determines, and drives corporate involvement in genocides. In section 3, we explore the specific role entrepreneurs and businesses played in three of the most uncontested genocides of recent history: the Jewish, Kurdish, and Darfurian genocides ${ }^{2}$. We integrate insights from these cases with findings from the literature in section 4 . In section 5 we conclude by offering several emerging lessons, and we venture a tentative conceptualization of the what, how, andparticularlywhy of business in genocide. Finally, in section 6 , we provide suggestions for further research.

\section{Corporate Complicity in Genocide: How and Why}

\subsection{How?}

The literature offers no consensus on the categorization of the roles businesses might play in genocide (Sherman, 2001). Five core positions (that can overlap and coexist) can

but try to stop such atrocities from being defined as genocide (Kaleck and Saage-Maass, 2010). The involvement of gold mining corporations such as Goldcorp, Nichromet Extractions, Hudbay Minerals, and BHP Billiton in Guatemala touches on similar, if less well-known contestations (van de Sandt, 2009; Nolin and Stephens, 2010; Hurtado, 2013). In Palestine, several cases have been made against companies facilitating Israeli occupation (Baars, 2006; Skinner, 2008). The companies in question have made extensive efforts to neutralize the implicit accusations of political genocide (politicide) in these cases (Moffatt, 2009).

2 It should be noted that these cases feature as illustrations and are not full-fledged case studies as the literature review underlying them is far from exhaustive. 
nevertheless be deduced from scholars discussions on corporate complicity: preventer, victim, indirect accomplice, direct accomplice, and perpetrator (Kaeb, 2008; Bernard, 2012; Chella, 2012). Preventershere, the emblematic Schindlers and Rusesabaginas of the world come to mindmight have striven to contribute to deescalation, early warning, or counteracting (Rieth and Zimmer, 2004; Oetzel et al., 2007; Bray and Crockett, 2012). Businesses considered victims might have lost personnel or assets or been forced to evacuate, a characterization that applies to some degree to almost all businesses in genocide-affected contexts. Perpetrators will have instigated and executed genocide as primary actors. While there are no documented cases of companies acting as the main perpetrator in registered genocide (Chella, 2012; Kelly, 2012), it should be kept in mind that in genocide the accomplice is often the real villain and the principal offender a small cog in the machine (Jacobson, 2005) [p.200]. In some cases, the violations are not perpetrated by the businesses, but on behalf of them, such as can be argued in the case of the forced relocation of indigenous people for the benefit of extractive industries (Manby, 2000; Clapham and Jerbi, 2001; Kelly, 2012) resulting in armchair perpetrators (Kyriakakis, 2012) or complicity by instigation (Jacobson, 2005).

It is therefore direct and indirect complicity that seem the most prevalent forms of business in genocide and are hence our main concern. Direct complicity is the provision of finance, material, infrastructure, human resources and capacity, and intelligence to the perpetrator of the genocide to the extent that the genocide is facilitated (i.e. could not have been implemented the way it was without the support of the company in question). In short, when companies are directly complicit in genocide, they are providing means with which wars are fought (Tripathi, 2010) [p.133]; they are, first and foremost, suppliers (Slim, 2012). Direct complicity is also often described as aiding and abetting and can concern the processes of ordering, instigating, soliciting, inducing, inciting, joining, planning, preparing, and conspiring (Chella, 2012). The main issue is supplying, through trade, taxes, royalties, and services or even through nonspecified payments, a genocidal group or regime with the resources and finances it needs to execute the genocide (Cooper, 2002; Ramasastry and Thompson, 2006; Martin-Ortega, 2008; Wennmann, 2009; Tripathi, 2010; Chella, 2012). There are also many instances where businesses have facilitated human rights violations by providing the necessary means of transportation or infrastructure, often through close cooperation dynamics with (para-) military or private security groups protecting the companys compounds or assets such as mines or oil fields (Manby, 2000; Khan, 2005; Kaeb, 2008; Moffatt, 2009; Tripathi, 2010; Chella, 2012). In such instances, providing training and/or equipment and sharing of intelligence are also forms of complicity (Martin-Ortega, 2008; Kaleck and Saage-Maass, 2010; Bray and Crockett, 2012).

Indirect complicity can fall in two categories. Beneficial complicity occurs when the company benefits from the genocide in some way, whether it was aware of or sympathetic to it or not. Silent complicity is apparent when the company does not contribute to or benefit from the genocide, but is aware of it and fails to distance itself from it (Jacobson, 2005). Legal scholars have been very keen to emphasize, silence is not neutrality (Clapham and Jerbi, 2001) [p.347] but an expression of moral support (Wettstein, 2010) $[\mathrm{p} .40]^{3}$.

3 Khan (2005) similarly distinguished between first-order involvement (actively helped to design and implement), second-order involvement (knowing their products would be used for repression), and 
These degrees and forms of business complicity in genocide can be established based on the notion of proximity to the violator (perpetrator), the violated (victims), and the violation (event) (Tripathi, 2010). Proximity, in turn, is closely related to the knowledge and foreseeability that companies had of the genocidal events going on, which can be assumed to depend on the geographical closeness to the event and the frequency and duration of the companys contact with the perpetrator (Huisman and van Sliedregt, 2010) [p.819]. See also Tripathi (2010) and Wettstein (2010). Several law cases have stressed that companies can be complicit even if they had not participated in the event or benefited from it; the mere knowledge that the event was going on generates complicity (Huisman and van Sliedregt, 2010). Indeed, the ostrich syndrome cannot be evoked as a legitimate defence (Bohoslavsky and Opgenhaffen, 2010) [p.171].

\subsection{Why?}

The main sentiment in the debate on what drives business to become involved in genocides derives from the businesses perceived self-interest. On the one hand, when it concerns companies positive behavior in contexts of genocide, it is often argued that they do so to avoid damage to their business and reputations (e.g. (Sherman, 2001; Rieth and Zimmer, 2004; Oetzel et al., 2007)). Here, the reputational damage of complicity, and subsequent economic losses, is a recurrent theme (Clapham and Jerbi, 2001; Sherman, 2001; Tripathi, 2010; Kelly, 2011; Amunwa, 2012).

On the other hand, when businesses are negatively complicit, it is also assumed that their self-interest is at the forefront (Sherman, 2001). Guaranteeing profit, preventing losses, maintaining a competitive advantage, protecting investments, and resource security are seen as the main motivations for corporations to act the way they do before, during, and after genocides (see e.g. (Jacobson, 2005; Jacobs, 2008; Ramasastry and Thompson, 2006; Martin-Ortega, 2008; Watts, 2008; Moffatt, 2009; Huisman and van Sliedregt, 2010; Chella, 2012; van Baar and Huisman, 2012).

Guidolin and Ferrara (2007) [pp. 1978-79] describe how the context of violent conflict often preceding and enabling genocide can have explicit benefits for companies, predominantly in the extractive industries. It installs entry barriers and thus limits competition, advantaging those businesses already involved; ensures that the bargaining power of conflict parties, often including the state, is low due to their need for immediate revenue to sustain the conflict, which can for instance undercut licensing costs; and lowers transparency, which makes profitable informal deals more likely. Bray and Crockett (2012) [p.1072] similarly note that postconflict countries constitute zones of untapped potential and pent-up consumer demand.

Such neutral profit-seeking behavior of companies is often seen, as exemplified by van der Wilt (2006) as a mitigating circumstance: After all, it seems far-fetchedand it may not even be fairto compare the diabolical minds who frame the extinction of a whole group, with businessmen whose prime interest is to make profits and who may have reconciled themselves with the possibility that their trade may support heinous

third-order involvement (benefited indirectly). 
international crimes" [p.255]. Jacobson (2005) argues: An accomplice may not even wish the crime to occur, but he is still willing to provide the aid to the principal offender for another reason, such as profit [p.205].

The problem is, however, that since the motive of self-interest is such an obvious explanation for complicity, it may importantly obfuscate other motivations or concerns leading company decision-making concerning genocide (Tripathi, 2010). The debate on what determines businesses decision making in and toward the genocidal process is a rather crude one, painting genocides as an opportunity for unproductive and destructive entrepreneurship (e.g. (Baumol, 1990)) exemplified by the arms trade or exploitable and lootable natural resources, and featuring companies as rational actors who cynically balance reputational damage on the one hand and the maximization of profit and minimization of loss on the other. The relative underdevelopment of this scholarly discussion seems to follow from the dearth of empirical data on companies motivations and considerations in this realm. For obvious reasonsbad public relationsvery little is known about the decision-making processes of companies confronted with genocide processes and the interests driving them (Sherman, 2001). It is indeed very hard to analyze the concrete roles of business in genocide because both good and bad deeds are often invisible, kept away from the public eye, and poorly documented (Wennmann, 2012) [p.934]. In many situations, moreover, businesses maintain they did not have any motivations one way or the other because their role was entirely unintentional. Indeed, Sherman (2001) [p.2] calls businesses concerns in decision making during genocides a black box for outsiders. While it is beyond the scope of this paper to veritably open this black box, in the following we will endeavor to at least develop some conceptual tools assisting future researchers in approaching it.

\section{Three Cases}

\subsection{The Kurdish Genocide in Iraq}

In 1987 and 1988 Saddam Hussein attacked the Kurdish community living in North Iraq with chemical and regular weapons, in what is known as the Anfal campaign. The attempt to purify the area and bring it under Arab influence resulted in up to 100,000 deaths, 182,000 disappeared people, and the displacement of some 1.5 million people (HRW, 1993; Kelly, 2013). The event has been recognized by both Iraqi and foreign courts and institutions as genocide.

Various national and international businesses were directly complicit in this genocide. In particular, a wide range of European, predominantly German, businesses supplied Saddam Hussein with the equipment and resources to implement his genocide (Hippler, 1991; HRW, 1993; Shenon, 2002; Kelly, 2013) ${ }^{4}$. Starcevic (1990) notes that no less than six Iraqi poison gas plants were built with German help, according to an independent

4 Kelly (2013) provides a full list of companies. The German companies he registers are: HerbergerBau; Karl Kolb; Ludwig-Hammer; Ceilcote; Klockner Industry; Schott Glass; Preussag; ReininghausChemie; Tafisa; Weco; Martin Merkel; Lewa Hebert. 
report commissioned by German authorities. Milhollin and Motz (2003) conclude, [T]he data reveals that firms in Germany and France outstripped all others in selling the most important thingspecialized chemical-industry equipment that is particularly useful for producing poison gas. Without this equipment, none of the other imports would have been of much use.

Kelly (2013) convincingly demonstrates that these businesses can be considered direct accomplices in the genocide because, first, they were aware of the genocidal intent of Hussein vis--vis the Kurdish population and the nature of the resources they sold him; and, second, they nevertheless continued to sell him these products without which the genocide could not have been executed. Kelly (2013) argues that the German companies that supplied Saddam Hussein with the ingredients for his chemical weapons program knew what he was up to because Iraqs use of chemical weapons against Iran during the 19801988 Iran-Iraq War had been widely published. The complicity of the companies, then, concerns the pregenocidal stage: the businesses helped Hussein prepare the genocide, but played no role in the execution of the genocide.

While it is credibly shown that these companies are in fact complicit, that they must have known what was about to happen, the question of why they nevertheless continued to participate is somewhat unsatisfyingly answered with the standard reference to profit maximization. While accounts of corporate complicity in the Kurdish genocide in Iraq provide welcome insights into how businesses can, seemingly quite intentionally, facilitate and enable genocide, they do not tell us much about the concrete decision-making processes driving the companies toward full-fledged involvement, nor do they shed light on the positioning of these companies in the postgenocidal phasefor instance, in response to survivors calls for prosecution (Dolamari, 2014).

\subsection{The Genocide on the Christian Population of Darfur, Sudan}

In the Darfur region of Sudan, government-sponsored and directed Janjaweed militias massacred some 80,000 people in the 20032005 period and displaced approximately two million from 1999 to 2006 (Clarke, 2012) ${ }^{5}$. These militias explicitly targeted the Christian African (as opposed to the Muslim Arab) population of the region, subjugating them to forced displacement, scorched earth, massacres, and systematic rape (Bannon et al., 2005) [p.3].

The ethnic targeting of the campaigns as well as their scope have led, if not to unanimity, then at least to a broad consensus among scholars that the events in Darfur can be considered a genocide (Bannon et al., 2005; Morse, 2005; Jacobs, 2008; Kelly, 2011). Forcese (2011), arguing for a case of correlation, if not causality, between business and genocide in Darfur, describes how Islamization of Christian and animist regions of Southern Sudan went hand-in-hand with the development of the oil fields and quotes a former employee of an international oil company saying that when oil profits start flowing into government hands, Christians in the South of Sudan will be largely eliminated within two years [p.42].

\footnotetext{
5 Figures are contested. Morse (2005) mentions two million dead and four million displaced
} 
Considering business complicity, the main attention is on the Canadian companies Talisman Energy Inc and Arakis Energy Corporation (Rieth and Zimmer, 2004; Morse, 2005; Watts, 2005; Jacobs, 2008; Huisman and van Sliedregt, 2010; Forcese, 2011; Kelly, 2011; Chella, 2012) the Swedish company Lundin (Morse, 2005; Batruch, 2010; Clarke, 2012) and the China National Petroleum Corporation (CNPC) that works through its subsidiary PetroChina and its Sudanese partner, the Greater Nile Petroleum Operating Company (GNPOC) (Morse, 2005; Jacobs, 2008; Kelly, 2011) ${ }^{6}$. These businesses have been associated with the ethnic cleansing of their oil extraction areas in southern Sudan as well as the resultant extrajudicial killings, torture, rape and physical destruction of civilian homes (see Kaeb (2008) p.342).

Most commentators describe this business involvement in terms of direct complicity that materializes through funding genocide by means of providing revenue to the Sudanese government (Bannon et al., 2005; Forcese, 2011; Kelly, 2011). Direct complicity was also apparent in the provision by companies of financial, logistical, material, or infrastructural assistance (Forcese, 2011). See also Morse (2005); Jacobs (2008). Forcese (2011)documents how Lundin serves broken military trucks, provides electricity lines to their barracks and even pipes water to the army camps and how airfields and roads built, used and sometimes operated by the oil company have been employed by the Sudanese military in attack against civilian population [p.42]. The CNPC also had contracts with Khartoum to secure their oil operations and allow Sudanese military forces to use the companies air strips, landing pads and mechanical support (Kelly, 2011). Such direct complicity thus is closely related to businesses (self-chosen) dependence on state(sponsored) troops for their security (Morse, 2005; Forcese, 2011).

With regard to the involvement of Chinese companies in the genocide in Darfur, Wettstein (2010) identifies a form of indirect complicity as well. He argues that the multinational companies that made money from the Beijing Olympics in 2008 implicitly endorsed and even further enabled the genocide in Darfur, which is crucially facilitated by CNPC. Bannon et al. (2005) [p.1516] make a similar case for the companies now operating in Sudan and suggest, the presence of these major energy companies also arguably legitimizes the government of Sudan and, in turn, its acts in Darfur (see also Popper (2007). While an exploration of the repercussions of such an argument (for instance, regarding the indirect complicity of European companies active in the United States waron-terror-related atrocities) is beyond the scope of this paper, the inevitable normalization and hence social acceptance of atrocities that follows from a lack of denouncement of associated companies seems intuitively evident.

Business complicity in the Darfur genocide concerns all phases of the genocidal process. First, much of the forced displacement and accompanying atrocities can be assumed to be implemented on behalf of businesses. Had these businesses not entered the scene, the genocide would have been much less likely to have occurredindeed, before the discovery of oil, violent conflict in the region never took on a genocidal nature and scale. Forcese (2011) argues that the main reason for the Sudanese government to abuse human rights

${ }_{6}$ Bannon et al. (2005) provides a comprehensive list of oil companies implicated in the Darfur genocide: Al-Thani Investment (UAE), Lundin Petroleum (Sweden), Marathon (USA), Nam Fatt (Malaysia), ONGC (India), PECD Berhad (Malaysia), PetroChina (China), Sinopec (China), Tatneft (Russia), Total Elf Fin (France), Vangold Resources Ltd (Canada), Videocon (India), White Nile (UK). 
was to supply resources to a company [p.37]. Second, as described above, businesses facilitated and enabled the perpetrators during the genocidal acts. Third, there are indications that businesses have also been involved in attempts to downplay the gravity of the events and deny their genocidal nature - see Batruch (2010) for an example in the case of Lundin.

As with the Kurdish genocide, commentators on the Darfur genocide seem relatively uninterested in the motivations for businesses complicity. Or, rather, they assume that the usual motivation of self-interest explains business behavior in the face of genocide (Forcese, 2011). However, the context of the extractive industry in which the Darfur genocide must be placed encourages analysts to slightly nuance this pure profit perspective. Jacobs (2008) for instance, suggests that for CNPC the main driver for involvement in Darfur is not so much profit, but resource security: securing a particular resource or raw material as a public good. Here, the distinction between private and public companies and potential ties between companies and governments might be particularly relevant (van Baar and Huisman, 2012). Possible reasons for companies to end their engagement in the Darfur genocide are predominantly sought in the economic disadvantages of a genocide stigma (Kelly, 2011). Yet, as Jacobs (2008) warns, only companies with an embedded human rights consciousness are susceptible to naming and shaming. State-owned enterprises with a frontier human rights [p.49] mentality that seek resource security are not. As with the Kurdish genocide, then, the ways in which businesses are involved in the Darfur genocide is relatively well documented, but the internal considerations and decision-making concerns that have led companies to this path and have guided them on it remain underresearched.

\subsection{The Holocaust}

The Holocaust, during which the Nazis exterminated six million European Jews from 1941 to 1945, does not require any introduction or elucidation here. The private sector played a significant role in the implementation of Hitlers envisioned extermination of the Jewish people. Strategic corporations, so-called W-Betriebe (Wehrbetriebe, or defense enterprises) important for the war effort, enjoyed privileges such as the use of forced labor and the acquisition of confiscated Jewish businesses (Stallbaumer, 1999; Wiesen, 1999; van Baar and Huisman, 2012). The postWorld War II Nuremberg trials are still a benchmark in todays jurisdiction considering business complicity in GMAs (Jacobson, 2005; Skinner, 2008; Huisman and van Sliedregt, 2010; Tripathi, 2010; Kelly, 2012).

In particular, four businesses were held accountable for their share in the Jewish genocide in the trials known as the Farben Case, the Krupp Case, the Flick Case, and, most infamous, the Zyklon B Case (Jacobson, 2005; Baars, 2006; Skinner, 2008). The Farben, Krupp, and Flick cases concerned German industrialiststhe former a chemical and pharmaceutical business, the latter two steel and coal businessesthat facilitated Hitlers war efforts, which in turn enabled the genocide (Stallbaumer, 1999; Wiesen, 1999; Stephens, 2002; Jacobson, 2005; Slim, 2012). These businesses were charged with participating in wars of aggression, in enslavement, in plunder and spoliation of property, and in a common plan or conspiracy to commit crimes against peace (Jacobson, 2005) 
[p.186].

Several authors also highlight the role of businesses in other sectors, such as those trading the gold stolen from the Nazis victims (Hayes, 1998; Wiesen, 1999; Kyriakakis, 2012) and the German banking and insurance sector (van Baar and Huisman, 2012). van Baar and Huisman (2012) present a case study about the German corporation Topf and Shne that built cremation ovens and ventilation systems for the gas chambers in Nazi extermination camps. Thus, while several cases will be discussed more in-depth here, ultimately, by 1943, almost every major private firm in Germany was among the exploiters (Hayes, 1998) [p.2]. They all had profited from the use of forced and slave labor, the Aryanization of Jewish property, and the plundering of companies in Nazi-occupied Europe (Wiesen, 1999).

The roles these businesses played in the Holocaust falls into the category of direct complicity: The businesses were used as instruments of economic mobilization for war by the main perpetrator (Jacobson, 2005) [p.171]. Where the Farben, Krupp, and Flick industrialists were held responsible for the broader war effort, that is, war crimes, Bruno Teschs company, the producer of Zyklon B, was considered complicit in genocide, as it had directly delivered the main resource used to execute this genocide.

Several studies also document the involvement of the private sector in the pregenocidal stagefor instance regarding the Aryanization of Jewish companies (Hayes, 1998)and the postgenocidal stage, particularly the peculiar initial lack of justification and legitimization and the subsequent denial of criminal behavior (van Baar and Huisman, 2012). With reference to their case study of Topf und Shne, van Baar and Huisman (2012) note the need for justification of the oven deliveries and ventilation systems to the extermination camps did not occur until the end of the war [p.13]. They conclude that, for a long time, in the understanding of those involved, there was possibly no criminal behavior that needed to be neutralized; the behavior was, presumably, not considered a crime. Wiesen (1999) however, stresses that this attitude was reversed from the 1960s onward when companies started to go to great lengths to generate sympathetic corporate histories and to exonerate themselves from accusations of involvement in Nazi crimes.

With regard to the Holocaust, the main interest of businesses to get engaged in genocide is considered to be, again, to do what businesses do best: make profit. Farben acted to enrich itself as part of a general plan to dominate the industries involved (Jacobson, 2005) [p.183]. According to Stallbaumer (1999) Flick was moved primarily by business as well, his interest being based on corporate expansion plans and an urge to protect market share. Hayes (1998) agrees that business self-interest was the overriding motive, but argues that such business self-interest often concerned survival rather than profit maximization. He states [p.2] that the point is not, as is so often assumed, that German corporations grew rich through participation in the Holocaust, since in general, they did not. The point is that they took what they could get and became part of it anyway.

As such, ideological motivations for business complicity in the Holocaust are often refuted in the literature. Germanys businesses did not march together like infantry men, into the conference room to do battle with the Jews (Hilberg 1962, as quoted in Stallbaumer (1999) p.2) and were not fanatical Nazis (van Baar and Huisman, 
2012). Scholars on the Holocaust have also identified more multifaceted drivers of business complicity in genocide, apart from the profit motive or nationalistic zeal. van Baar and Huisman (2012)'s article focusing on the German business Topf und Shne, for instance, pays attention to intracompany dynamics that might generate business complicity, such as competition among subunits, corporate culture, and normalization and neutralization. They suggest that while at I. G. Farben, competition between corporations was an important explanation for their involvement in the Holocaust, at Topf, it was mostly competition within the corporation that explains their involvement (van Baar and Huisman, 2012) [p.10]. They Van Baar document in great detail how professional zeal, more than moral or profit considerations, determined the companys drive to participate, and participate with dedication, in the genocide perpetrated on the Jews. Striving for innovation and technical perfection seems to be the most prominent motivation for Topf und Shne, and it was the company, rather than the SS, that took the initiative to improve the ovens and ventilation systems (van Baar and Huisman, 2012) [p.910]. This reading resonates with the broader literature on business culture and the general nature of bureaucracies where the bureaucratic nature of organizations and the emphasis on goal attainment, along with the division of labour [can] make it unnecessary for employees to think beyond what they are told to do, causing managers to be solely concerned with reaching targets, and victimization disappears behind cost and benefit analysis (van Baar and Huisman, 2012) [p.2].

\section{Discussion and Analysis}

Combining the main tenets of the literature on corporate complicity in genocide with the case-specific observations presented above yields several insights that can help in further conceptualizing the what, the how, and the why of businesses involvement in genocides.

\subsection{What}

In asking the question what type of business tends to be involved in genocide, both the general literature and scholars working on our three cases are especially concerned with two dimensions: size and sector. Academics have mostly been interested in big businesses complicity in genocide of multinationals (Chella, 2012; Voillat, 2012). In the sources about the three genocides discussed above, as well, relatively little is said about the role of national businesses or local entrepreneurs in genocidal processes. This is remarkable because much of the corporate complicity in human rights violations involves what are essentially small business networks, many very informal and even illegal (Sherman, 2001). As van Baar and Huisman (2012) suggest, there are important differences between family enterprises and multinational companies when it comes to motivations to get involved in genocide. With regard to the Holocaust, for instance, Hayes (1998) is convinced that [e]nvy and greed ... found their home to a much greater extent among ... participants in those middle ranges of economic life where Jews remained conspicuous as competitors and middlemen, that is to say, among mostly self-employed shopkeepers, artisans, peasant 
proprietors, and professionals, especially medical doctors, than in big businesses and corporations [p.5].

Moreover, a companys size importantly affects its governance and investment structure (partnership or subcontractor; sole operator or consortium), including its relations with the host government (often the genocide perpetrator) that shapes the ways companies might be involved in genocides (Sherman, 2001). This last issue is also stressed by (Watts, 2008), who, with reference to firms operating in the extractive industries, points out that most African governments collaborate with multinational resource enterprises through state-owned enterprises, particularly in the oil industry.

The organizational structures of businesses operating in areas where genocides are likely to occur are often purposefully vague (Stephens, 2002; Watts, 2005; Guidolin and Ferrara, 2007). This exacerbates problems of corporate accountability and the legal challenges to distinguish between individual directors and managers and the company (Martin-Ortega, 2008; Chella, 2012). The conviction of Stephens (2002) that whatever it is, it can be held accountable", may be too optimistic.

Apart from overlooking the role of smaller and more localized companies, the literature tends to prioritize certain sectors over others in discussing corporate complicity in genocide. For instance, as exemplified in the Darfur genocide discussed, there has been extensive attention paid to oil companies in Africa as well as Colombia, Ecuador, India, and Indonesia (Huisman and van Sliedregt, 2010; Martin-Ortega, 2008; Sherman, 2001; Stephens, 2002; Rieth and Zimmer, 2004; Watts, 2005); for corporations mining for diamonds and gold in Angola, Sierra Leone, and the Democratic Republic of Congo (DRC) (Cooper, 2002; Guidolin and Ferrara, 2007; Huisman and van Sliedregt, 2010; Martin-Ortega, 2008; Tripathi, 2010); for timber businesses in Liberia (Cooper, 2002; Sherman, 2001) and for coltan miners in the DRC (Cooper, 2002). Indeed, due to the specific characteristics of the extractive industriesasset specificity, long production cycles, valuable concession agreementsthey are much less likely to disengage from conflict zones and hence more probable to become involved in genocide (Sherman, 2001) ${ }^{7}$.

For similar reasons, the lords of war trading and selling the weapons with which genocides are executed are also well covered by the literature, for instance via the emblematic van Kouwenhove (Chella, 2012; Huisman and van Sliedregt, 2010; Kaleck and Saage-Maass, 2010; Tripathi, 2010; Wennmann, 2012) and van Anraat (Huisman and van Sliedregt, 2010; Tripathi, 2010; van der Wilt, 2006) cases. The former was accused of trading with a genocidal regime in Liberia and Sierra Leone, and the latter provided Saddam Hussein with the weapons to execute the genocide on Iraqs Kurds. The role of mercenaries and private armies and security companies, often operating in the wake of multinationals active in the extractive industries, is also broadly discussed (Bray and Crockett, 2012; Guidolin and Ferrara, 2007; Huisman and van Sliedregt, 2010; Kaeb, 2008; Percy, 2012; Ramasastry and Thompson, 2006; Sherman, 2001; Watts, 2005).

Remarkably, while in the empirical literature about the Jewish and Kurdish genocide the focus has been on manufacturing companies, much less attention is being paid to

\footnotetext{
7 Even if disengagement has taken place in some cases, for instance in response to campaigns against
} blood diamonds. 
the productive and service sectors. Considering that the main role that companies are seen to play in genocides is that of financing, it is also noticeable that there is not more attention to the role of the banking sector in GMAs such as displayed in the work of Bohoslavsky and Opgenhaffen (2010), which touches on banks involvement in mass atrocities in Argentina and Colombia and the Holocaust; and Weiss and Shamir (2012) who discusses the complicity of Israeli Banks in Israels mass killings in the Gaza Strip.

Based on the above, we suggest that more attention is due on the role of smaller firms and family enterprises in genocide to counterbalance the current obsession with multinationals in this context. Perhaps even more important, the roles of domestic and foreign firms need to be juxtaposed more systematically, so as to conceptualize the differences that were evident in the cases discussed here between, for example, German companies in the context of the Holocaust and German companies operating in Iraq under Saddam Hussein. This might also provide more handles to study the different, and often purposively ambiguous, institutional ties that firms have with (host and home) governments.

\subsection{How}

Business involvement is a feature of all genocides. The cases outlined in this paper, however, confirm the literatures emphasis on complicity (as opposed to perpetration). We illustrated that in genocides, business complicity is both direct and indirect (or silent). Direct complicity, for instance through providing weapons (in the Kurdish case) and/or providing facilities and finances (in the Darfur and Holocaust cases) reflects that businesses were aware of, or could and hence should reasonably have known about, ongoing genocide. Indirect complicity, such as described in the case of the Darfur genocide, mostly is apparent in the legitimizing and normalizing of business complicity in the genocide.

The cases also reveal a nuance not regularly noted in the literature regarding the stages of the genocidal process. Here, we see variation across the cases. In the Kurdish case, the companies providing the chemicals needed for Saddam Husseins extermination of the Kurds helped prepare and enable the genocide, but played no role in the actual execution. In Darfur, businesses were complicit in both the pregenocide phaseproviding the incentive for genocidal activities and enabling them through financing the main perpetratorand, in some cases, during the genocideactively supporting and facilitating genocidal campaigns. In the Holocaust, German businesses normalized genocidal tendencies in the phase leading up to the Endlsung (the final solution) and were active implementers and facilitators during the genocide. Where analyses of the Kurdish and Darfur genocides pay little attention to the postgenocide phase, moreover, studies of business complicity in the Holocaust do explore the contribution of businesses to after-the-fact normalization and rationalization processes. 


\subsection{Why}

We particularly noted an important difference between the cases regarding the analysis of the motives for business complicitya topic that is relatively underappreciated in the literature we reviewed. In the literature, and also with regard to the Kurdish and Darfur genocides, there is ample attention to the how, but the why of business complicity is assumed rather than critically explored. The pursuit of profit is considered the default driver of all business behavior, no matter the circumstances. The lack of insights about why businesses are involved in genocide in the first place and why, subsequently, they opt for specific forms and degrees of complicity is partly a result of the fact that the perspective of the businesses in question is not solicitedand where it is, is hardly received. While it might for various reasons be difficult to get to internal business motivations and reflections, these nevertheless seem essential to take the next step in understanding how and why businesses enable genocideand potentially limiting business complicity in genocide (Brants, 2007).

The literature on corporate complicity in the Holocaust provides a useful starting point. First of all, the more in-depth discussions of specific companies involvement in that genocide reveals that there is an important difference between companies actively taking the initiative vis--vis genocide perpetrators and those more passively meeting the perpetrators requests or ordersan insight closely related to the distinction between domestic and foreign companies involvement in genocides. The case of the Holocaust also suggests that the more historic the genocide in question, the more likely the theme of business motivation will be picked upnot least because the (legal, socioeconomic, and hence economic) consequences for businesses will diminish and their willingness to reflect on their previous conduct presumably increases. In addition, what sets the overall analysis of business complicity in the Holocaust apart from other cases of business complicity in genocide is the contributions of criminologists to the substantial legal approach to the topic, which has linked business complicity in genocide to studies on other corporate crimes. As argued in section 3, this allows for more nuanced institutional analyses of drivers for corporate decision-making in genocidal contexts (Brants, 2007; van Baar and Huisman, 2012).

The overall emphasis on the conduct of individual persons rather than the operation of businesses as organizations or institutions might also be the result of this disciplinary bias toward the legal studies in which the discussion on the liability of companies seems to overshadow the potential responsibility of businesses beyond their individual leader or otherwise responsible person (Brants, 2007). This bias, however, might have political roots as well. Wiesen (1999) writes: During the trials at Nuremberg, the American prosecutors were careful not to portray the proceedings as attacks on the market economy, but rather as attempts to punish individuals who had committed crimes. This was despite the fact that while individuals were nominally on trial, the Krupp Company itself, acting through its employees, violated international law (Skinner, 2008).

Emphasizing the agency of individuals, according to Wiesen (1999), was for a long time convenient to keep analyses away from seeing the behavior of businesses as a result of capitalist structures, a hotly contested issue during the cold war when Marxists 
wanted to prove and anti-Marxists wanted to refute the claims that capitalism and fascism were linked. In the postcold war era, however, a more criminologicalor generally politicalperspective would be in order. More attention to the motives driving business complicity and a reconsideration of the dialectic between structure and agency in the question of business complicity in genocide might also allow for a less rigidly legal understanding of the relations between perpetrators (usually state actors) and accomplices (often companies) in genocide.

This paper has been explicitly explorative and has been concerned with locating gaps in the conceptual and empirical literature on corporate complicity in genocide. We did so by means of three concrete case illustrations. Nevertheless, we do have the ambition to provide explicit conceptual handles for further research into this topic. We venture some proposals in the section that follows.

\section{Concluding Remarks}

We started this paper mentioning that it may, on the face of it, not be logical for businesses to become engaged in genocide because it is bad for their businesses and their reputations. However, as shown throughout this paper, reality is more complex. Businesses, as we have illustrated, hardly ever commit or perpetrate genocide, because their role generally consists of complicity. This also means that their motivation need not be positive or active, that is, to commit genocide and destroy a group of peoplewhich would indeed be a rather peculiar businesses objective. As an accomplice, businesses merely need to have the negative or passive incentive to not intervene or disengage even while knowing what is going on.

To better understand therefore the complicity of business in GMA, first and foremost, we see a need for a shift from diagnostic attention on how businesses are engaged in genocide to a more analytical exploration of why businesses have made the choices they did in the process of their engagement with genocide. This is also necessary to advance the debate on how to hold businesses accountable for gross human rights violations and moreover to provide incentives for businesses not only to avoid doing harm but also to proactively, preventively strive to protect and extend human rights (see, e.g. Wettstein (2010)). To move the explanatory discussion beyond the platitudes of profit maximization and loss minimization, however, a more case-specific analysis is required. For instance, as we illustrated, the size, domestic or foreign background, and sector will shape the institutional structures governing a company and its relation with genocide-perpetrating governments.

In light of this, what should and can we ask from businesses? There are ample guidelines for businesses to avoid complicity in human rights violations and genocide, culminating in the Norms on the Responsibilities of Transnational Corporations and Other Business Enterprises with Regard to Human Rights (from 2003) and the United Nations Guiding Principles on Business and Human Rights (from 2011). In terms of the former as Oetzel et al. (2007) summarize, multinational enterprises can (and should) 
leave, withhold payments that might support violence, publicly condemn violence, provide support to peacekeeping missions, lobby the government, and explicitly support the rule of law. In terms of the latter (the Ruggie Framework), the implementation of a set of human rights due-diligence instruments are promoted. Thus, Econsense (2014) for instance lists more than 120 tools and resources to support such a human rights due diligence.

Rieth and Zimmer (2004) stress that even without such explicit policies and tools, businesses are a major contributor to the prevention of genocides if they strengthen equitable and inclusive economies and build human capital (see also Bray and Crockett (2012)). Complementing liability with a culture more geared toward responsibility could further open up the debate on what businesses can and should do in the face of genocidal events and move away from only criticizing business for what they should not do. Yusuf (2008) suggests a fundamental rethinking of the role of the private sector in society and its position vis--vis the public sectora suggestion that, in fact, goes far beyond the theme of business complicity in genocide. He argues [p.99] that

" [i]t can be posited that the social contract between the individual and the state dictates that concessions (sub-contracts in contract theory) made by the latter operate to bind the privy (sub-contractor) to the head contract to the extent of the expected impact of such operations. In that way, licensees and concessionaires (such as MNCs [multinational corporations]) can be made to take on some of the obligations of their principal (the state) and become bound to fulfil them based on the doctrine of privity of contract. They could then become substantially bound to perform some of the important terms of the contract between state and society."

In other words, economic contracts would include a default sociopolitical clause, which would mean that in liaising with governments, companies would be forced to take on some of these governments accountability vis--vis a countrys citizens.

A perhaps more concrete potential of focusing on responsibility instead of liability or only avoiding doing harm is that it takes seriously the options of businesses in genocidal settings beyond the usual panacea of disengagement. Businesses have long argued that withdrawal has human security costs as well (Manby, 2000; Kelly, 2011; Weiss and Shamir, 2012). Popper (2007) writes that, in the case of an international engineering company, all stakeholders advised ... against withdrawing from the country. To do so, they said, would undermine the fragile reconstruction process and deny the country much-needed infrastructure [p.28]. Weiss and Shamir (2012) discuss the case of Israeli utility service providers in Gaza that were pressured by the Israeli government to stop their provision as part of the governments sanction regime. In this case, scholars argued, disengagement rather than continuation of involvement would constitute a human rights violation.

Ultimately, however, to be able to help businesses steer away from complicity in the future and toward promotion of human rights, we first need to better understand what drove them toward complicity in the past. In this paper, we have demonstrated that further research on business complicity in genocide would do well to explore the why of such complicity rather than merely the what or how. It is an understanding of the motivations 
and considerations of companies, more than a technical documentation of their behavior that will yield the insights needed to work toward prevention.

\section{Acknowledgements}

We are grateful to Charles H. Anderton, Jurgen Brauer, and four anonymous reviewers for their comments on earlier versions of this paper. The usual disclaimer applies.

\section{References}

Amunwa, B. (2012). Fueling the violence: Oil companies and armed militancy in nigeria. Accessed online http://platformlondon.org/wp-content/uploads/2012/08/Fuelling-theviolence-Oil-Companies-and-Armed-Militancy-in-Nigeria-August-2012.pdf.

Baars, B. (2006). Corrie et al v. caterpillar: Litigating corporate complicity in israeli violations of international law in u.s. courts. In M. Lau and F. Nasrallah, eds., Yearbook of Islamic and Middle Eastern Law. Vol. 12. Leiden, The Netherlands: Brill, 97134.

Bannon, A., Cover, A., Ghoshal, N., Marcuse, D., Robinson, N., and Shivaram, S. (2005). An analysis of select companies operations in sudan: A resource for divestment. The Allard K. Lowenstein International Human Rights Project Yale Law School. New Haven, CT: Yale University.

Batruch, C. (2010). Lundin petroleum abs experience in east africa: The role of the private sector in conflict prone countries. Economics of Peace and Security Journal, $5(2): 5-9$.

Baumol, W. (1990). Entrepreneurship: Productive, unproductive and destructive. Journal of Political Economy, 98(5):893921.

Bernard, V. (2012). Globalisation will only mean progress if it is responsible. International Review of the Red Cross, 94(87):88191.

Black, E. (2001). IBM and the Holocaust: The Strategic Alliance between Nazi Germany and Americas Most Powerful Corporation. New York: Crown Books.

Bohoslavsky, J. and Opgenhaffen, V. (2010). The past and present of corporate complicity: Financing the argentinean dictatorship. Harvard Human Rights Journal, 23(1):157203.

Brants, C. (2007). International Handbook of White-Collar and Corporate Crime, chapter Gold Collar Crime. The Peculiar Complexities and Ambiguities of War Crimes, Crimes Against Humanity and Genocide, page 309326. New York: Springer.

Bray, J. and Crockett, A. (2012). Responsible risk-taking in conflict-affected countries: The need for due diligence and the importance of collective approaches. International Review of the Red Cross, 94(887):106989. 
Brueck, T., Naudé, W., and Verwimp, P. (2013). Business under fire: Entrepreneurship and violent conflict in developing countries. Journal of Conflict Resolution, 57(1):3-19.

Chella, J. (2012). The complicity of multinational corporations in international crimes: An examination of principles. PhD dissertation, Bond University.

Clapham, A. and Jerbi, S. (2001). Categories of corporate complicity in human rights abuses. Hastings International and Comparative Law Review, 24:33949.

Clarke, P. (2012). Oil money paid for sudans genocide. Afton Bladet, April 14.

Cooper, N. (2002). State collapse as business: The role of conflict trade and the emerging control agenda. Development and Change, 33(5):93555.

Dolamari, M. (2014). Kurdish people want german companies to be put on trial. BasNews, March 13.

Econsense (2014). Respecting human rights: Tools and guidance materials for business. Berlin: Forum for Sustainable Development for German Business.

Forcese, D. (2011). Militarized oil in sudans oilfields: Lessons for canadian foreign policy. Canadian Foreign Policy Journal, 8(3):37-56.

Guidolin, M. and Ferrara, E. L. (2007). Diamonds are forever, wars are not: Is conflict bad for private firms? American Economic Review, 97(5):197893.

Hayes, P. (1998). Profits and persecution: German big business and the holocaust. J. B. and Maurice C. Shapiro Annual Lecture, Washington, DC, February 17.

Hippler, J. (1991). Iraqs military power: The german connection. Middle East Report, 21(168).

HRW (1993). Genocide in iraq: the anfal campaign against the kurds. New York: Human Rights Watch.

Huisman, W. and van Sliedregt, E. (2010). Rogue traders: Dutch businessmen, international crimes and corporate complicity. Journal of International Criminal Justice, 8(3):803-28.

Hurtado, L. (2013). Despite historic conviction, genocide continues in guatemala. Food First Website, May 16, http://upsidedownworld.org/main/guatemala-archives33/4300-despite-historic-conviction-genocide-continues-in-guatemala(accessed May 12, 2015).

Jacobs, L. (2008). Differentiated corporate legal consciousness in international human rights disputes: Security and transnational oil companies in sudan. Asia Pacific Program on Dispute Resolution Research Notes, 1(3):37-49.

Jacobson, K. (2005). Doing business with the devil: The challenges of prosecuting corporate officials whose business transactions facilitate war crimes and crimes against humanity. Air Force Law Review, 56(1):167-233. 
Kaeb, C. (2008). Emerging issues of human rights responsibility in the extractive and manufacturing industries: Patterns and liability risks. Northwestern Journal of International Human Rights, 6(2):32753.

Kaleck, W. and Saage-Maass, M. (2010). Setting the framework: Corporate accountability for human rights violations amounting to international crimes: The status quo and its challenges. Journal of International Criminal Justice, 8(3):699724.

Kelly, M. (2011). Ending corporate impunity for genocide: The case against chinas state owned petroleum company in sudan. Oregon Law Review, 90(2):41348.

Kelly, M. (2012). Prosecuting corporations for genocide under international law. Harvard Law and Policy Review, 6:(2):33967.

Kelly, M. (2013). Never again? german chemical corporation complicity in the kurdish genocide. Berkeley Journal of International Law, 31(2):34891.

Khan, I. (2005). Understanding corporate complicity: Extending the notions beyond existing laws. Business Human Rights Seminar, London. December 8, https://www.amnesty.org/fr/documents/pol34/001/2006/en/.

Kyriakakis, J. (2012). Developments in international criminal law and the case of business involvement in international crimes. International Review of the Red Cross, 94(887):9811007.

Manby, B. (2000). Shell in nigeria: Corporate social responsibility and the ogoni crisis. New York: Carnegie Council on Ethics and International Affairs.

Martin-Ortega, O. (2008). Business and human rights in conflict. Ethics and International Affairs, 22(3):27383.

Milhollin, C. and Motz, K. (2003). The means to make the poisons came from the west. New York Times, April 13.

Moffatt, S. (2009). 'bilin and beyondprosecuting corporate complicity in war crimes under canadian law. M.A. thesis, University of Toronto.

Morse, D. (2005). How oil drives the genocide in sudan. Sudan Tribune, August 18, http://www.sudantribune.com/spip.php?article11203.

Naudé, W. (2009). Making Peace Work: The Challenges of Social and Economic Reconstruction, chapter Entrepreneurship, Post-Conflict, pages 251-263. Basingstoke: Palgrave Macmillan.

Nolin, C. and Stephens, J. (2010). We have to protect the investors: development and canadian mining companies in guatemala. Journal of Rural and Community Development, 5(3):3770.

Oetzel, J., Getz, K., and Ladek, S. (2007). The role of multinational enterprises in responding to violent conflict: A conceptual model and framework for research. American Business Law Journal, 44(2):33158. 
Percy, S. (2012). Regulating the private security industry: A story of regulating the last war. International Review of the Red Cross, 94(887):94161.

Popper, R. (2007). Abb and sudan: The value of stakeholder engagement. Embedding Human Rights in Business Practice II. New York: United Nations Global Compact and Office of the U.N. Commissioner for Human Rights, pages 26-30.

Ramasastry, A. and Thompson, R. C. (2006). Commerce, crime and conflict : Legal remedies for private sector liability for grave breaches of international law. FAFO Report 365. Olso, Norway: FAFO.

Rieth, L. and Zimmer, M. (2004). Transnational corporations and conflict prevention: The impact of norms on private actors. Center for International Relations, Law and Conflict Studies. Tuebingen, Germany: University of Tuebingen.

Shenon, P. (2002). Declaration lists companies that sold chemicals to iraq. New York Times, December21, pages http://www.nytimes.com/2002/12/21/world/threatsresponses-suppliers-declaration-lists-companies-that-sold-chemicals-iraq.html.

Sherman, J. (2001). Private sector actors in zones of conflict: Research challenges and policy responses. International Peace Academy Workshop Report. New York: International Peace Institute.

Skinner, G. (2008). Nurembergs legacy continues: The nuremberg trials influence on human rights litigation in u.s. courts under the alien tort statute. Albany Law Review, 71(1):32167.

Slim, H. (2012). Business actors in armed conflict: Towards a new humanitarian agenda. International Review of the Red Cross, 94(887):90319.

Stallbaumer, L. (1999). Big business and the persecution of the jews: The flick concern and the aryanization of jewish property before the war. Holocaust and Genocide Studies, 13(1):1-27.

Starcevic, N. (1990). Many german firms helped build iraqi arsenal. AP News, October 29.

Stephens, B. (2002). The amorality of profit: Transnational corporations and human rights. Berkeley Journal of International Law, 20(1):4590.

Stokes, P. and Gabriel, Y. (2010). Engaging with genocide: The challenge for organization and management studies. Organization, 17(4):46180.

Sweetman, P. (2009). Business, conflict resolution and peace-building: Contributions from the private sector to address violent conflict. Abingdon: Routledge.

Tripathi, S. (2010). Business in armed conflict zones: How to avoid complicity and comply with international standards. Politorbis, 50(3):13142.

Urwand, B. (2013). The collaboration: Hollywoods pact with hitler. Cambridge, MA: Belknap Press. 
van Baar, A. and Huisman, W. (2012). The oven builders of the holocaust: A case study of corporate complicity in international crimes. British Journal of Criminology, 52(6):103350.

van de Sandt, J. (2009). Mining conflicts and indigenous people in guatemala. Cordaid and the Amsterdam University Law Faculty.

van der Wilt, H. (2006). Genocide, complicity in genocide and international v. domestic jurisdiction: Reflections on the van anraad case. Journal of International Criminal Justice, 4(2):2395.

Voillat, C. (2012). Pushing the humanitarian agenda through engagement with business actors: The icrcs experience. International Review of the Red Cross, 94(887):10891115.

Watts, M. (2005). Righteous oil? human rights, the oil complex, and corporate social responsibility. Annual Review of Environmental Resources, 30(1):373407.

Watts, M. (2008). Blood oil. the anatomy of a petro-insurgency in the niger delta, nigeria. Economies of Violence Working Papers No. 22, Institute of International Studies. University of California, Berkeley, CA.

Weiss, D. and Shamir, R. (2012). Corporate accountability to human rights: The case of the gaza strip. Harvard Human Rights Journal, 24(1):1558.

Wennmann, A. (2009). Getting armed groups to the table: Peace processes, the political economy of conflict and the mediated state. Third World Quarterly, 30(6):112338.

Wennmann, A. (2012). The role of business in armed violence reduction and prevention. International Review of the Red Cross, 94(887):919-940.

Wettstein, F. (2010). The duty to protect: Corporate complicity, political responsibility and human rights advocacy. Journal of Business Ethics, 96(1):3347.

Wiesen, S. (1999). German industry and the third reich: Fifty years of forgetting and remembering. Dimensions: A Journal of Holocaust Studies, 13(2).

Yusuf, H. (2008). Oil on troubled waters: Multinational corporations and realising human rights in the developing world, with specific reference to nigeria. African Human Rights Law Journal, 1(1):79107. 